\title{
Can a School Operational Assistance Fund Program (BOS) Reduce School Drop-Outs During The Post-Rising Fuel Prices in Indonesia? Evidence from Indonesia
}

\begin{tabular}{c} 
Bayu Kharisma \\
Department of Economics, Faculty of Economics and Business, University of Padjadjaran \\
Jl. Dipati Ukur No. 35 Bandung, 40132, Indonesia \\
Email: bayu.kharisma@unpad.ac.id \\
\hline
\end{tabular}

Recieved: August 2017 | Revised: November 2017 | Accepted: November 2017

\begin{abstract}
This study aims to analyze the impact of school operational assistance fund program (BOS program) on the dropout rate during the post-rising fuel prices using Indonesian Family Life Survey (IFLS) and difference in difference approach. The results showed that the impact of BOS on the dropout rate of students aged 7-15 years during the period investigated in this study was lower than those who did not receive BOS fund, but it was not statistically significant. In the meantime, if the account of the research is to be limited to the influenc e of students aged 16-20 years who had previously received the benefit of BOS, it shows that BOS program had a positive influence to the dropout rates. However, children aged 16-20 years who had not previously received benefits BOS negatively affect the dropout rates. Based on this fact, the benefit of the BOS following the fuel price hike in Indonesia during the research period did not seem to be particularly effective in lowering the dropout rate.
\end{abstract}

Keywords : School Operational Assistance Fund Program (BOS program), Dropout rate, Eise of fuel price in Indonesia, Difference-in-Difference (DiD)

JEL Classifications: I38, H52

How to Cite: Kharisma, B. (2018). Can a School Operational Assistance Fund Program (BOS) Reduce School Drop-Outs During The Post-Rising Fuel Prices In Indonesia? Evidence From Indonesia. Jurnal Ekonomi Pembangunan: Kajian Masalah Ekonomi dan Pembangunan, 19(1), 12-23. doi:https://doi. org/10.23917/jep.v18i2.4942

DOI: https://doi.org/10.23917/jep.v18i2.4942

\section{Introduction}

The increase in world oil prices in 2005 reached its highest level for the past 25 years, which was about $\$ 70$ per barrel, had forced the government to reduce subsidies for fuel oil (BBM) twice both in March and October (Bank Indonesia, 2005). As a logical consequence of the reduction of fuel subsidies, the domestic fuel prices had a rise. In an effort to reduce the adverse effects of fuel price rising, the government had reallocated its budget to 4 (four) programs which were designed to reduce the burden of the people, notably the poor. Those four programs were programs in education, health, rural infrastructure, and cash transfers. One of the programs in the field of education was the School Operational Assistance (BOS).

BOS program was commenced in July 2005 and was addressed to the elementary schools and junior secondary schools to reduce the burden of the people, particularly the poor, in financing education following a rise in fuel prices. 
In contrast to its predecessor, the Fuel Subsidy Reduction Compensation Program (PKPS-BBM), in which the program was given in the form of scholarships (Student Special Assistance - BKM) to students who were considered to be in a poor financial condition, BOS was given to the school. BOS funds were allocated based on the number of students, with the calculation of Rp 235,000 per student per year for primary school level and $R p$ 324,500 per student per year for junior secondary schools. National budget (APBN) allocation for BOS funding for the period of July to December 2005 was Rp. 5.136 trillion, an increase of about 8 (eight) times more than the budget for BKM program for elementary and junior high for the period from January to June 2005 (SMERU, 2006).

BOS program was a further development of the social safety net programs (JPS) education of the government in the period 1998-2003 and a compensation program in fuel subsidy reduction carried out during the period of 2003-2005. The program was meant to be a school operating cost subsidies to all students of compulsory education and channeled directly through the educational unit with an expectation that educational unit would no longer impose the burden of school operating costs to its students, especially students from poor communities.

BOS funds aimed to liberate the cost of education for students who can not afford, to ease the burden for other students, to lower the limited access to basic education which is expected to improve the school participation rate in order to support achievement of nine years compulsory basic education program as stated in law no. 20 2003 on National Education System article 5, paragraph (1) which states that "Every citizen has the same right to obtain quality education," and article 11, paragraph (1) states "the Central Government and Local Government shall provide services and ease, and ensure the implementation of quality education for every citizen without discrimination" In this context, in principle, the BOS program was launched by the government as an effort to enhance people's access, especially for students from poor or disadvantaged, to quality education in order to nine years compulsory study.

Contrary to the expectation, there is a fact that the dropout rate in primary education (in this case the elementary and junior high) is still high despite the School Operational Assistance (BOS) has been held, especially in the level of Junior secondary school (SMP). For more details can be seen in Table 1 .

Table 1 shows that the dropout rate for primary school level after the BOS program implementation in 2005 has decreased from $2.90 \%$ to $2.21 \%$. On the other hand, the dropout rate for SMP (junior secondary school) actually increased from $1.78 \%$ to $2.52 \%$ in the academic year 2006/2007. Thus, it can be said that the School Operational Assistance (BOS) did not fulfill the expectation.

There are several possible factors that may lead to the issue of an increase in the dropout rate, but the most dominant influence on the dropout rates are economic factors (Shahidul \& Karim, 2015). In addition, problems in junior secondary school dropout is not solely caused by economic inability, but also due to other factors such as student delinquency and the attraction to work. BOS funds which is intended to relieve the burden on the poor students to go to school, when implemented has not yet able to assist all poor students in the school. This is due to much misuse of the funds that have been allocated resulting in the BOS funds did not meet the expectation.

Table 1. Dropout Rate (\%) in Period 2002/2003 - 2006/2007

\begin{tabular}{cccccc}
\hline \multirow{2}{*}{$\begin{array}{c}\text { Level of } \\
\text { Education }\end{array}$} & \multicolumn{5}{c}{ Academic Year } \\
\cline { 2 - 6 } & $\mathbf{2 0 0 2 / 2 0 0 3}$ & $\mathbf{2 0 0 3 / 2 0 0 4}$ & $\mathbf{2 0 0 4 / 2 0 0 5}$ & $\mathbf{2 0 0 5 / 2 0 0 6}$ & $\mathbf{2 0 0 6 / 2 0 0 7}$ \\
\hline SD+MI & 2.94 & 2.92 & 2.75 & 2.90 & 2.21 \\
SMP+MTs & 2.84 & 2.48 & 2.49 & 1.78 & 2.52 \\
\hline
\end{tabular}

Jurnal Ekonomi Pembangunan, ISSN 1411-6081, E-ISSN 2460-9331 
Research on the impact of government programs on educational subsidies for dropout rates and school enrollment had mixed results. Cameron (2002) in his study on the role of social networking scholarship programs (social safety net scholarships) on the dropout rate during the crisis in Indonesia in 1998 showed that the SSN education is effective in reducing dropouts at the junior secondary school (SMP) but did not provide significant impact on the level of elementary school (SD) and High School (SMA). Meanwhile, Borraz and Gonzalez (2009) conducted a study on conditional cash transfer programs (conditional cash transfer) for the basic education sector to the level of school enrollment and dropout in Uruguay, where the results of research is that it had no impact on the level of participation in school and out of school, but instead reducing the rate of working girls. Duflo (2000) conducted a study on the impact of the program INPRES to the achievement level of education and income in Indonesia. Her research results showed that the Presidential Instruction Program for elementary school construction in Indonesia led to an increase in educational attainment in Indonesia. The program has led to a significant increase in the proportion of the population to complete basic education. This increase was translated into an increase in salary for each additional school built per 1,000 children. Furthermore, Sparrow (2004) analyzed the impact of the scholarship program in Indonesia conducted in 1998 to look at access to education for the poor during the economic crisis. The program has increased the number of the school, particularly for children of primary school age out of poor rural households. Besides, the scholarship has helped household consumption during the crisis, as well as relieving pressure on household investments in education and the use of child labor. Although there are several different studies that have been done, but in general government programs in education have a crucial impact in improving school enrollment and reduce dropout rates. In some cases, these programs may increase the number of children in school, lower levels of child labor, increase spending on groceries (food expenditure), improve public health and reduce poverty (Ponce and Bedi, 2010).

Based on concerns about the dropout rate at the primary level after BOS previous empirical studies carried out and this paper is intended to analyze the impact of the implementation program School Operational Assistance (BOS) on dropout rates in Indonesia. Broadly speaking, this paper is organized as follows: section 2 will present an overview of the BOS program in Indonesia. Section 3 presents the research method and data. Meanwhile, section 4 presents the results and discussion. Section 5 provides some conclusions from the results of research that is then covered with policy recommendations in section 6 .

\section{An Overview of BOS Program in Indonesia}

The background of the BOS is the policy of the government to reduce fuel subsidies and reallocate most of the budget which is designed to reduce the burden of the poor due to the impact of rising fuel prices. There are 4 (four) sectors of budget fuel subsidy among other things: education, health, rural infrastructure assistance and direct cash subsidy (SLT).

In the field of education, the concept of Subsidy Reduction Compensation Program Fuel (PKPSBBM) for elementary and junior high students initially Special Assistance program (BKM) is directly given to the students / poor students who have been selected by the school according to the received budget allocation. The program has been transformed into Programme school Operational Assistance (BOS), which is directed to be managed by schools in accordance with the provisions. The amount of funds allocated to each school set was based on the number of students.

BOS program was commenced in July 2005 and the funds were channeled through this program were directly transferred from the central government to the bank account of each school. The funds are intended to reduce or eliminate the cost of tuition, while maintaining the quality 
of education. According to the BOS program guidelines in 2005 , operating costs may include the cost of registration of new students, textbooks and reading books, stationery, test, development and training of teachers, school maintenance, transportation costs for poor students, salaries of teachers, as well as the cost of electricity, water and telephone. Although the primary objective of the BOS program is for equity and access expansion, BOS program is also a program for improving the quality, relevance and competitiveness as well as for governance, accountability and public image. The target of BOS itself was all institutions at the primary school, junior secondary school, both public and private, in all provinces in Indonesia.

Throughout the BOS program, each executive education programs should pay attention to the following (Ministry of National Education, 2005). First, BOS should become an important means of accelerating the completion of the nine year compulsory basic education program. Second, by the implementation of BOS, there should be no poor students drop out of school for nonpayment of dues / payments made by the school / madrasa /

$Y_{i j t}=\alpha_{0}+\alpha_{1} B O S_{i j}+\gamma t_{t}+\delta B O S_{i j} * t_{t}+x_{i j t}^{\prime} \beta+v_{i j t}$

Where $Y_{i j t}$ is a variable that describes the number of dropouts individual $i$ in household $j$ in year $t$, which refers to the individual student dropouts aged 7-15 years (elementary and junior secondary school age), BOS is a dummy variable, $1=$ invididu $i$ in households receiving $\operatorname{BOS} j$ in year $t, 0=$ individual $i$ in household $j$ who did not receive BOS program in year $t, t$ is a dummy variable where $1=$ the period of time in 2007 and 0 $=2000$. Meanwhile, $\mathrm{X}_{\mathrm{ij}}$ are variable characteristics of households and individuals, while $\mathrm{v}_{\mathrm{ijt}}$ is the error term for individual $i$ in household $j$ in year $t$.

The interest parameters in equation (1) is $\delta$, the difference in difference estimator that measures the impact of the program on the treatment of BOS. BOS program given to all individuals who attend school at the age of 7-15 ponpes (Islamic Boarding School). Third, children at the primary school graduates should be encouraged to continue his/her education to junior secondary school. There should be no graduates of SD / MI / equivalent who cannot continue to SMP / MTs / SMPLB by reason of the high cost of going to school. Fourth, the head of school / madrasah / ponpes (Islamic Boarding School) enlist and invite students of SD / MI / SDLB that will graduate and who is likely to drop out to be accommodated in the SMP / MTs / SMPLB. Similarly, when there is a child who have been out of education for quite some times but this student still have an interest to continue his/her study, he/she should be invited back to school.

\section{Research Method and Data}

This paper uses estimation techniques difference-in-difference (DID) to analyze the impact of the implementation of the School Operational Assistance (BOS) the dropout rate in Indonesia through the following equation (Bertrand, Duflo \& Mullainathan., 2004):

years (elementary and junior secondary school age). In this paper, the program uses a binary variable, where the treatment is individual $i$ in school at the age of 7-15 years and receive the benefits of BOS. Meanwhile, the control group is the individual $i$ are not in school at the age of 7-15 years and did not receive the benefits of BOS. Thus, measuring changes $\delta$ BOS program beneficiaries between the ages of 7-15 years who were on treatment relative to individuals who were in the control group. Furthermore, to avoid bias, this paper will include all information used in the calculation, particularly for students who have previously received the benefit of BOS, but when the study period was between 16-20 years of age or not the elementary and junior secondary school age. 
Avalaible online at http://journals.ums.ac.id, Permalink/DOI: 10.23917/jep.v19i1.4942

Jurnal Ekonomi Pembangunan: Kajian Masalah Ekonomi dan Pembangunan, 19 (1), 2018, 12-23

Table 2. Descriptive Statistics

\begin{tabular}{lcc}
\hline \multicolumn{1}{c}{ Description } & $\begin{array}{c}\text { Mean 2000 } \\
\text { (Std. Dev.) }\end{array}$ & $\begin{array}{c}\text { Mean 2007 } \\
\text { (Std. Dev.) }\end{array}$ \\
\hline The number of school dropouts aged 7-15 years & 0.1119 & 0.1444 \\
& $(0.4365)$ & $(0.4485)$ \\
Number of BOS recipients aged 7-15 & 1.2781 & 1.3301 \\
The number of children aged 16-20 years who have & $(0.9317)$ & $(1.0111)$ \\
previously received the benefits of BOS & 0.2951 & 0.3312 \\
The number of household members & $(0.5486)$ & $(0.6371)$ \\
& 5.0447 & 5.3263 \\
Age of household head & $(1.9543)$ & $(2.0916)$ \\
& 44.1721 & 44.4599 \\
Marital status of household heads (married $=1)$ & $(12.4087)$ & $(12.5455)$ \\
Gender of household head (male=1) & 0.8535 & 0.8530 \\
Percapita expenditure (IDR) & $(0.3536)$ & $(0.3541)$ \\
& 0.8487 & 0.8535 \\
Number of household members who work in the household & $(0.3583)$ & $(0.3536)$ \\
The employment status of head of household (work $=1)$ & 505770 & 359544 \\
Education of household head (years) & $(481030.5)$ & $(411432.7)$ \\
The number of children attending & 2.0856 & 2.1506 \\
& $(1.2248)$ & $(1.2726)$ \\
& 0.8914 & 0.8909 \\
& $(0.3111)$ & $(0.3118)$ \\
\end{tabular}

Sources : IFLS 3 dan IFLS 4

Equation (1) above, may lead to bias if there are some household characteristics and time invariant unobserved which might affect the outcome. In addition, bias may occur due to endogeneity problems arising from the household's decision to participate in the program or not (self-selection bias). Thus, to control the placement of the program is not random (non-

$Y_{i j t}=\alpha_{0}+\alpha_{1} B O S_{i j}+\gamma t_{t}+\delta B O S_{i j} * t_{t}+x_{i j t}^{\prime} \beta+v_{i j t}$

This paper uses survey data IFLS collected by the RAND Corporation. The panel data used in this paper is from IFLS-3 and IFLS-4 (The Indonesia Family Life Survey) in 2000 and 2007 to capture the period before and after the effect random) and unobserved charateristics of households and individuals in the anticipated participation in the program by the method of fixed effects at the household level so that the problem can be overcome the bias (Khander, Koolwal \& Samad, 2010). Thereby, by using household fixed effects, estimation of equation (1) is:

of the BOS program dropout age 7-15 years (age levels primary and secondary) in the event of fuel price hikes in Indonesia in 2005. IFLS is a longitudinal survey of the field of socio-economic and health, where the survey was conducted by 
Jurnal Ekonomi Pembangunan: Kajian Masalah Ekonomi dan Pembangunan, 19 (1), 2018, 12-23

collecting individual data, including households and smallest unit of communities where they live, and what health and education facilities are used.

The first wave IFLS-1 was conducted in 1993 to include respondents of approximately 7244 households. IFLS second wave (IFLS2) was conducted in 1997 and in 1998 there was an additional survey (IFLS2 + ) with 25 percent of the sample intended to measure the impact of short-term political and economic crisis in Indonesia. Furthermore, IFLS3 the full sample was carried out in 2000. Meanwhile, IFLS4 was implemented in late 2007 to early 2008 with the same respondents in 1993. A total of 13,535 households and 44,103 individuals was surveyed in all phase (Strauss et al, 2009).

The data is expected to provide information on the socio-economic characteristics that may affect the dropout rate at the elementary and junior secondary school age, among others, the number of household members, age of household head, household employment status during the first years, the marital status of household, gender of household head, per capita expenditure, number of household members who work in the last 1 year household, employment status of household head, number of school children, school age and sex of school children.

Before estimating equation (1) and (2), there will be a prior discussion on descriptive statistics on the number of school dropouts aged 7-15 years. Table 2 shows the difference between the average number of school dropouts in 2000 and 2007. Statistically, the average number of school dropouts in 2007 was amounted to 0.1444 which meant that it was 0.0325 higher than average number of school dropouts in 2000. Number of BOS recipients aged 7-15 in 2007 had average stats of 1.3302 or 0.0521 higher compared to the average number of recipients aged 7-15 BOS in 2000. Meanwhile, the number of children aged 16-20 years who have previously received the benefits of BOS had higher average in 2007 than in 2000 to reach an average of 0.0361 .

\section{Result and Discussion \\ 4.1 Difference in Difference Estimates of BOS Impact to Dropout Rate Aged 7-15 Years}

Table 3 shows the dropout rate before and after the BOS program. Based on the estimation, it was found that the difference in the change in dropout rates between the control group and the treatment group (treatment) was not statistically significant. This analysis showed that students aged 7-15 years enrolled in school and received the benefits of the BOS program affecting dropout rates decreased from 1.001 points to 0.053 or decreased by an average of 0.948 points. Meanwhile, children aged 7-15 years who did not receive the benefit of the BOS program is relatively more effective in reducing the dropout rate from 1.024 to 0.072 points or down by an average of 0.952 points. The results showed that the difference in difference of BOS impact on students aged 7-15 years who received such assistance benefits against dropout rate is 0.004 points lower than children who did not receive assistance BOS. Nevertheless, these results are not statistically significant. However, the difference in difference estimation is still not acceptable because it does not include all information used in the calculation, especially for children who have previously received benefits BOS but now at the age between 16-20 years.

If we only consider the influence of students aged 16-20 years who have previously received the benefits of BOS, the results indicate that the differences in changes in dropout rates between the control group and the treatment group (treatment) was statistically significant at the 99\% level. Based on the estimation results, it was indicated that students aged 16-20 years who have previously received benefits BOS affect the increased dropout rate from 0.008 to 0.027 points or increased dropout rates by an average of 0.019 points. While children aged $16-20$ years who had not previously received benefits BOS actually negatively affect the dropout rate from 0.168 to 0.033 points or dropout rates decreased by an 
average of 0.135 points. Meanwhile, the difference in difference estimation results indicate that the impact of aid on students aged 16-20 BOS who have previously received the dropout rate is 0.154 points lower than children who did not receive assistance BOS.

There are several possible explanations of the results. First, at the beginning of the implementation of the BOS program benefits for dropout prevention (DO) is still low, especially in the age of 13-15 years, equivalent to junior level. That's because most parents who have children affected dropout (DO) (some of whom had dropped out of school in FY 2005/2006) are not aware of the BOS program at their child's school. In addition, the school also unaware that the BOS program, is actually aimed to prevent dropouts, and it was less emphasized in the socialization of the program and the receiving assistance treaty. Therefore, schools tended not to make special efforts to prevent school drop-out rates. Second, the dropout problem in junior secondary schools also are not solely due to the inability of the economy, but also due to other factors such as student delinquency and the attraction of working (SMERU, 2006). Third, during the initial implementation of the BOS program, the distribution of funds allegedly problematic, such as the inflation of students, submission without permission and appropriate use of funds no designation, no effective socialization by DEPDIKNAS (Ministry of National Education, 2005b).

There are only three (3) provinces that can be considered as well implementation of this program, namely Jambi, Gorontalo and East Kalimantan (BAPPENAS, 2008). Fourth, the impact of the BOS program would be effective to decrease dropout rate in the long run. Fifth, there are many factors why a child of school age was unable to complete basic education in Indonesia. These factors can be grouped into 3 (three) main thing though all of them seem intertwined with each other, namely: (1) Institutional, which is factors existed in the school environment and this includes teachers, curriculum, appropriateness or relevance, quality management and its achievement. (2) Contextual, i.e. factors related to where and how the child's residence including the location and family background and the ability of the household economy. (3) Individual, which is related to young people themselves including academic performance, gender and age (USAID, 2006).

Table 3. Impact Evaluation Result

\begin{tabular}{|c|c|c|c|}
\hline \multirow[b]{2}{*}{ Model } & \multicolumn{3}{|c|}{ Dropout Rate Aged 7 - 15 years } \\
\hline & $\begin{array}{l}\text { Before } \\
(2000)\end{array}$ & $\begin{array}{l}\text { After } \\
(2007)\end{array}$ & After - Before \\
\hline \multicolumn{4}{|l|}{ a. $7-15$ years } \\
\hline $\begin{array}{l}\text { Children aged } 7-15 \text { years who did not receive the } \\
\text { benefit of the BOS program (Control) }\end{array}$ & 1.024 & 0.072 & -0.952 \\
\hline $\begin{array}{l}\text { Students aged } 7-15 \text { years enrolled in school and } \\
\text { received the benefits of the BOS program ( Treatment) }\end{array}$ & 1.001 & 0.053 & -0.948 \\
\hline Difference & -0.023 & -0.019 & 0.004 \\
\hline \multicolumn{4}{|l|}{ b. $16-20$ years } \\
\hline $\begin{array}{l}\text { Children aged } 16-20 \text { years who did not receive the } \\
\text { benefit of the BOS program (Control) }\end{array}$ & 0.168 & 0.033 & -0.135 \\
\hline $\begin{array}{l}\text { Students aged } 7-15 \text { years enrolled in school and } \\
\text { received the benefits of the BOS program ( Treatment) }\end{array}$ & 0.008 & 0.027 & 0.019 \\
\hline Difference & -0.16 & -0.006 & $0.154 * * *$ \\
\hline \multicolumn{4}{|c|}{$\begin{array}{l}\text { Values in parentheses are robust standard errors } \\
* \text { Significant at the } 10 \%,{ }^{* *} \text { significant at the } 5 \% \text { and } * * * \text { significant at } 1 \%\end{array}$} \\
\hline \multicolumn{4}{|c|}{ Jurnal Ekonomi Pembangunan, ISSN 1411-6081, E-ISSN 2460-9331 } \\
\hline
\end{tabular}


Avalaible online at http://journals.ums.ac.id, Permalink/DOI: 10.23917/jep.v19i1.4942

Jurnal Ekonomi Pembangunan: Kajian Masalah Ekonomi dan Pembangunan, 19 (1), 2018, 12-23

Tabel 4. Regression results of the Impact Beneficiary BOS to Dropout Rate Age 7-15 Years

\begin{tabular}{|c|c|c|}
\hline Model & OLS & FE \\
\hline Receive the benefits of BOS impact aged 7-15 years & $\begin{array}{c}-1.0439 * * * \\
(0.0319)\end{array}$ & $\begin{array}{c}-0.9410^{* * *} \\
(0.0595)\end{array}$ \\
\hline Year $(2007=1)$ & $\begin{array}{c}-0.0278 \\
(0.0411)\end{array}$ & $\begin{array}{l}-0.0222 \\
(0.0747)\end{array}$ \\
\hline DID & $\begin{array}{l}0.02556 \\
(0.0413)\end{array}$ & $\begin{array}{c}0.0253 \\
(0.0763)\end{array}$ \\
\hline The number of household members & $\begin{array}{c}0.0408^{* * *} \\
(0.0047)\end{array}$ & $\begin{array}{c}0.0391^{* * *} \\
(0.0080)\end{array}$ \\
\hline Household members who work in the household & $\begin{array}{l}-0.0075 \\
(0.0064)\end{array}$ & $\begin{array}{c}0.0035 \\
(0.0114)\end{array}$ \\
\hline Age of household head (years) & $\begin{array}{c}-0.0009 * * * \\
(0.0003)\end{array}$ & $\begin{array}{l}-0.0009 \\
(0.0007)\end{array}$ \\
\hline Gender of household head $($ male $=1)$ & $\begin{array}{l}-0.0298^{*} \\
(0.0169)\end{array}$ & $\begin{array}{c}0.0033 \\
(0.0340)\end{array}$ \\
\hline The employment status of head of household $($ work $=1)$ & $\begin{array}{c}0.0364 * * \\
(0.0145)\end{array}$ & $\begin{array}{c}0.0071 \\
(0.0270)\end{array}$ \\
\hline Log(per capita expenditure) & $\begin{array}{c}-0.0144^{* *} \\
(0.0064)\end{array}$ & $\begin{array}{c}0.0035 \\
(0.0140)\end{array}$ \\
\hline Household head education (years) & $\begin{array}{c}-0.0066^{* * *} \\
(0.0009\end{array}$ & $\begin{array}{c}0.0005 \\
(0.0038)\end{array}$ \\
\hline Marital status of household heads (married $=1$ ) & $\begin{array}{c}0.0072 \\
(0.0168)\end{array}$ & $\begin{array}{l}-0.0239 \\
(0.0351)\end{array}$ \\
\hline The number of children attending & $\begin{array}{c}-0.0394^{* * * *} \\
(0.0060)\end{array}$ & $\begin{array}{c}-0.0272^{* * *} \\
(0.0096)\end{array}$ \\
\hline School age children (years) & $\begin{array}{c}-0.0026^{* *} \\
(0.0013)\end{array}$ & $\begin{array}{l}-0.0016 \\
(0.0021)\end{array}$ \\
\hline _cons & $\begin{array}{c}1.2511^{* * * *} \\
(0.0831)\end{array}$ & $\begin{array}{c}0.8631^{* * *} \\
(0.1826)\end{array}$ \\
\hline R-squared & 0.5296 & 0.4850 \\
\hline Fixed Effect & No & Yes \\
\hline
\end{tabular}
Description :

Values in parentheses are robust standard errors

* Significant at the $10 \%, * *$ significant at the $5 \%$ and *** significant at $1 \%$.

4.2 Estimated Impact Beneficiary BOS to Dropout Rate Age 7-15 Years Accounted for Socioeconomic Characteristics of Households and Individuals

In Table 4 shows the results of the BOS program impact on the number of dropout age 7-15 years taking into account some characteristics of households and individuals, which use fixed effect estimation techniques at the household level to control the effects and time invariant unobserved heterogeneity that may affect outcome. Based on the estimation results indicate that students aged 7-15 years enrolled in school and receive the benefits of BOS (DID) impact on improving the dropout rate by 0.0253 points. However, the coefficient is not statistically significant. In the meantime, if viewed from the characteristics of the household, the number of household members positively affect the dropout rate of 0.0391 and statistically significant at the $99 \%$ confidence level. This is in line with research showing that the number of family members tends to lead to high dropout rates, which resulted in a large 
number of family heads into a busy family to meet family needs and also led to a lack of parental supervision of their children's education and to work for survival of their families, causing vulnerability to dropout rates (Cameron, 2002).

Children characteristics which were statistically significant effect on the dropout rate is the number of children attending. The number of children attending negatively affect the dropout rate of 0.0272 at $99 \%$ confidence level. That is, if there is an increase in the number of children in school by 1 point it will reduce the dropout rate by 0.0272 points cateris paribus assumption. These results are consistent with the results of previous studies (Dehejia et al., 2006) which states that parental factors, such as level of ability, awareness and parental concern in placing high value on formal education are less likely to send their children to work, but trying to improve their children's school participation. Thus, the number of children attending it will indirectly increase school enrollment and reduce dropout rates. Meanwhile, the variable number of household members who work in the household, age of household head, gender of household head when a man, The employment status of head of household if it works, per capita expenditure and household head education consecutive positive effect on dropout rates decreased. While the variable age of household head, marital status of household heads were married household negatively affect the dropout rate decreased by 0.0009 and 0.0239 . However, all of the coefficients of these variables did not show statistically significant results.

\subsection{Estimated Impact Beneficiary BOS to Total Dropout Rate Age 16-20 Years Ac- counted for Socioeconomic Characteristics of Households and Individuals}

Table 5 shows the estimation taking into account students who have previously received benefits BOS but is now at the age between 16-20. Coefficient BOS impact on dropout rates showed statistically significant results. These results are consistent with the calculation of difference in difference, where the impact of the BOS program to students who have previously received assistance and are now aged $16-20$ years had a positive effect on dropout rates by 0.1637 points and statistically significant at the $99 \%$ confidence level. Household characteristics that negatively affect the dropout rate is the employment status of head of household if it works that reached 0.1263 and statistically significant at the $95 \%$ confidence level. That is, if there is an increase of 1 point employment status of household heads work it will reduce the dropout rate by 0.1263 points cateris paribus assumption.

This result shows that dropout rates are caused not only by the economical inability, but also when the head of the household does not work (unemployed). This will result in their children to be employed to help meeting the economic needs of families that are burdened with these economic problems. In the long run this can lead to schoolage children becoming forced to leave school and enter the labor market at a young age in order to meet the economic needs of their families (ILO, 2006). Conversely, if the head of the household work so that parents tend not to involve their children to help meet the economic needs of the family and are trying to keep their children in school. It may indirectly lower the dropout rate. Meanwhile, the child characteristics that influence the rate of decline in the number of children dropping out of school is a school. The number of children attending negatively affect the dropout rate decreased by 0.0372 points at the $90 \%$ confidence level. That is, if there is an increase of 1 point the number of school age then it will reduce the dropout rate by 0.0372 points cateris paribus assumption. Furthermore, the other variables are the number of household members, number of household members who work in the household, age of household head, sex households, expenditure per capita, education of household head, marital status of household heads and school age children not statistically significant. 
Avalaible online at http://journals.ums.ac.id, Permalink/DOI: 10.23917/jep.v19i1.4942

Jurnal Ekonomi Pembangunan: Kajian Masalah Ekonomi dan Pembangunan, 19 (1), 2018, 12-23

Tabel 5. Regression results of the Impact Beneficiary BOS to Dropout Rate Age 16-20 Years

\begin{tabular}{|c|c|c|}
\hline Model & OLS & FE \\
\hline Receive the benefits of BOS impact aged 16-20 years & $\begin{array}{c}-0.0910 * * * \\
(0.0184)\end{array}$ & $\begin{array}{l}-0.0583 \\
(0.0486)\end{array}$ \\
\hline Year $(2007=1)$ & $\begin{array}{l}-0.0282 \\
(0.0194)\end{array}$ & $\begin{array}{c}-0.2124^{* * *} \\
(0.0618)\end{array}$ \\
\hline DID & $\begin{array}{c}0.0650 \\
(0.0195)\end{array}$ & $\begin{array}{c}0.1637 * * * \\
(0.0591)\end{array}$ \\
\hline The number of household members & $\begin{array}{c}0.0336 * * * \\
(0.0061)\end{array}$ & $\begin{array}{c}0.0224 \\
(0.0152)\end{array}$ \\
\hline Household members who work in the household & $\begin{array}{l}-0.0028 \\
(0.0072)\end{array}$ & $\begin{array}{c}0.0230 \\
(0.0229)\end{array}$ \\
\hline Age of household head (years) & $\begin{array}{c}-0.0012^{* * *} \\
(0.0004)\end{array}$ & $\begin{array}{l}-0.0026 \\
(0.0023)\end{array}$ \\
\hline Gender of household head $($ male $=1)$ & $\begin{array}{c}0.0123 \\
(0.0220)\end{array}$ & $\begin{array}{c}0.0577 \\
(0.0913)\end{array}$ \\
\hline The employment status of head of household $($ work $=1)$ & $\begin{array}{c}0.0235 \\
(0.0169)\end{array}$ & $\begin{array}{c}-0.1263^{* *} \\
(0.0617)\end{array}$ \\
\hline Log(per capita expenditure) & $\begin{array}{l}-0.0113 \\
(0.0080)\end{array}$ & $\begin{array}{c}0.0155 \\
(0.0302)\end{array}$ \\
\hline Household head education (years) & $\begin{array}{c}-0.0066 * * * \\
(0.0013)\end{array}$ & $\begin{array}{l}-0.0132 \\
(0.0095)\end{array}$ \\
\hline Marital status of household heads (married $=1$ ) & $\begin{array}{l}-0.0392 * \\
(0.0228)\end{array}$ & $\begin{array}{l}-0.0246 \\
(0.0739)\end{array}$ \\
\hline The number of children attending & $\begin{array}{c}-0.0169 * * \\
(0.0075)\end{array}$ & $\begin{array}{c}-0.0372 * \\
(0.0217)\end{array}$ \\
\hline School age children (years) & $\begin{array}{c}-0.0119 * * * \\
(0.0044)\end{array}$ & $\begin{array}{c}0.0165 \\
(0.0141)\end{array}$ \\
\hline _cons & $\begin{array}{c}0.4117 * * * \\
(0.1227)\end{array}$ & $\begin{array}{l}-0.1601 \\
(0.5240)\end{array}$ \\
\hline R-squared & 0.0879 & 0.1220 \\
\hline Fixed Effect & No & Yes \\
\hline
\end{tabular}

Description :

Values in parentheses are robust standard errors

* Significant at the $10 \%, * *$ significant at the $5 \%$ and *** significant at $1 \%$.

\section{Conclusion}

The Impact of The School Operational Assistance (BOS) impact on students aged 7-15 years the dropout rate during the study was lower than those not receiving assistance BOS, but not statistically significant. In the meantime, if we only take into account the influence of students aged 16-20 years who have previously received the benefit BOS dropout rate results show that the impact of even BOS positive effect on dropout rates. However, children aged 16 -20 years who had not previously received benefits BOS actually negatively affect dropout rates. Based on this fact, the benefits of the BOS during post fuel price hike in Indonesia during the study period was deemed not effective in lowering the dropout rate at the primary level. Meanwhile, other factors that influence the dropout rate in this paper during the study period, were: head of household status if working, household size and the number of children attending. 
This paper is expected to provide an initial evaluation of the impact of the BOS program dropout children. However, there are still many limitations in this paper, mainly related to the methodology and there are many other factors that affect the supposedly dropout rates. For example, the influence of geographical factors, individual access to school, gender, quality of schools, the quality of teachers and teaching, public and private schools, curriculum and more.

\section{Policy recommendations}

During the study period showed that the impact of BOS on dropout rates are still relatively low or ineffective. Therefore, the BOS program still need to be addressed. Some of the most urgent needs to be repaired in the future if only socializing is done the school and other stakeholders to emphasize that the BOS aims among other things to prevent dropout. In addition, the amount of funds itself felt all along has not been sufficient and implementing mechanisms have not been optimal. With the austerity budget for fuel subsidy cuts in the amount of BOS is still very likely to be upgraded. In addition, the participation of all parties need to escort the implementation of the BOS program, ranging from socialization to the level of supervision.

\section{References}

Bank Indonesia. (2005). "Laporan Perekonomian Indonesia 2005”. Bank Indonesia.

Bertrand, M, E. Duflo \& S. Mullainathan., (2004) "How much should we trust differences-indifferences estimates?". Quarterly Journal of Economics 119 (1), 249-275

Cameron, L. (2002). "Can A Public Scholarship Program Successfully Reduce School DropOuts in a Time Of Economic Crisis? Evidence from Indonesia”. Dept of Economics. University of Melbourne.

Center of Data and Statistic for Education. (2008). "National Education Data Overview
2007/2008”. Ministry of National Education. Jakarta.

Dehejia, R et al. (2006). "Child Labor and Agricultural Shocks". Journal Development Econonomics 81:80-96

Duflo, E. (2000). "Schooling and Labor Market Consequences of School Construction in Indonesia: Evidence from an Unusual Policy Experiment". The American Economic Review.

ILO. (2006). "Pasar Tenaga Kerja Orang Muda Indonesia dan Dampak Putus Sekolah Dini serta Pekerja Anak". Organisasi Perburuhan Internasional . Jakarta. 2006.

Khander, S.R., Koolwal, G.B., \& Samad, H.A. (2010). "Handbook on Impact Evaluation, Quantitative Methods and Practices". Washington DC: The World Bank

Ministry of National Education. (2005a). "School Operational Handbook (BOS) Handbook for Free Education in a Nine Year Compulsory Learning Period". 2005

Ministry of National Education. (2005b), "Strategic Plan Ministry of National Education 20052009”. Jakarta

Ponce, J \& Bedi S.,A. (2010). "The Impact of a Cash Transfer Program On Cognitive Achievement: The Bono De Desarrollo Humano Of Ecuador". Economics of Education Review 29 (2010) 116-125. Elsevier.

Shahidul, S.M \& Karim, A.H.M \& Zehadul. (2015). Factors Contributing To School Dropout Among The Girls: A Review Literature. European Journal of Research and Reflection in Educational Sciences. Vol. 3 No. 2. 2015.

SMERU. (2006). "Kajian Cepat PKPS-BBM Bidang Pendidikan: Bantuan Operasional Sekolah (BOS) 2005”. Jakarta

Sparrow, R. (2004) "Protecting Education for the 
Avalaible online at http://journals.ums.ac.id, Permalink/DOI: 10.23917/jep.v19i1.4942

Jurnal Ekonomi Pembangunan: Kajian Masalah Ekonomi dan Pembangunan, 19 (1), 2018, 12-23

Poor in Times of Crisis: An Evaluation of a Scholarship Program in Indonesia”. SMERU Working Paper. October 2004

Strauss, J et.al (2009). "The Fourth Wave of The Indonesia Family Life Survey : Overview and Field Report. Volume 1". RAND Labor and Population Working Paper Series.
USAID. (2006). "Apa yang sedang dikerjakan di Tingkat Nasional untuk Memastikan Semua Kaum Muda Indonesia yang Menyelesaikan Pendidikan Dasar? Laporan Penelitian Tingkat Putus Sekolah di Tingkat Nasional. USAID : Decentralizaed Basic Education 3 : Life Skills for Youth 